\title{
MENA countries: economic and political perspectives in the aftermath of the Arab Spring - an introduction
}

\section{Carlo Altomonte and Massimiliano Ferrara}

The Middle East and North Africa (MENA) region's economies have always been characterized by economic volatility and social disparities.

A long history of state-driven development led to a rise in human development, reducing poverty, but it also exacerbated social exclusion. Notwithstanding the reforms introduced in the 1980s and 1990s, the problem of social exclusion has not been solved in the subsequent decades. Such reforms, indeed, included large-scale privatizations and reduction of barriers to trade and, together with the increase in oil prices, they stimulated growth in the Arab region, but only a small politically connected elite was able to access the benefits of the growth process. This same sense of economic exclusion and social injustice fuelled recent episodes of violence and protests characterizing the so-called Arab Spring.

Between 2010 and 2011 the first mass mobilizations overthrew the government in Egypt and in Tunisia, while a wave of popular protests spread all over the MENA countries, although with different intensities and outcomes. In the short term, the so-called Arab Spring has increased political uncertainty and instability in the region, further exacerbating those socioeconomic problems that were among the root causes of the protests, causing the economic outlook in the region to deteriorate. In the long term, however, the effects of the Arab Spring are still uncertain. They could offer an opportunity to begin a real process of political and economic reform in the region.

This uncertainty leads to a still weak actual macroeconomic trend, frail from many points of view.

\section{I.1 THE POLITICAL PERSPECTIVE}

Huntington (1996) attributed decisive importance to the role played by geography in the development and spread of democratic institutions. The 
theorist of the clash of civilizations thesis also advanced his ideas on the development of democracy (Huntington, 1991). In his interpretation, the process of democratization developed through three consecutive waves: the first involving North America and Western Europe, the second concerning Southern Europe, Latin America and parts of Asia, and finally the third having its focus on Eastern Europe (basically the countries formerly belonging to the Soviet bloc). Huntington died in 2008 so he was not able to observe what, in the eyes of many analysts, seemed to act as a fourth wave of democracy in the Southern Mediterranean. However, it appears to be still too early to determine whether this process, largely exogenous, will be successful or whether it will fail.

In recent years in particular two phenomena have placed the democratic question at the centre of the Mediterranean political agenda:

- On the northern shore, the difficulties encountered on the path of the European integration, which now seems much more laborious and complex than twenty years ago. Some of the German media showed no hesitation in defining 'democracy as garbage' when the Berlin-Paris axis rejected Papandreou's idea of proposing a referendum to the Greek people on the European rescue plan.

- On the other side of the Mediterranean basin, riots broke out in December 2010 and quickly spread in North Africa and the Middle East under the inappropriate definition of 'Arab Spring' (a definition that we use for convenience only).

\section{2 NORTH AFRICA}

The key element in defining North Africa is the Sahara, a huge box of sand. If we try to turn the map upside down - as suggested by Braudel (1949) - it will seem to fall on us. In the era of globalization, we live the myth that the digital revolution and the development of the means of transport have made the world smaller and more homogeneous. But the desert escapes this over-simplification.

In the desert the springs - as we know them - never bloom. Similarly, the Arab Spring seems to have been too short as it soon degenerated into an endless autumn.

At the basis of the riots along the southern shore of the Mediterranean, there were several factors: the demographic explosion in the 1970s and 1980s that two/three decades later inevitably produced youth unemployment in the area; the closure of the relief valve of migration (towards Europe) on account of the global economic crisis; the development of new 
technologies that enabled the Mediterranean riots to spread with a few clicks, bypassing - as never before - the censorship of the regimes.

In addition, the riots did not have identical consequences throughout the area because of the intervention, in some territories, of external factors including the decisive involvement of foreign powers (for example, France in Libya). We could simplify the effects of the riots of the so-called Arab Spring in this way: large protests in Algeria, change of government in Morocco, removal or killing of the heads of state in Tunisia, Egypt and Libya. Nevertheless, the analysis of the phenomenon must be much more complex because we are registering a counter-revolution, where the aspirations for freedom (and democracy?) have been frustrated by the reaction of the military hierarchy who have always been at the helm of those states from the second half of the twentieth century onwards.

The situation never seems quiet even in the Maghreb but still there are two critical points concerning the north-eastern part of the continent. One year after Gheddafi's death, Libya is still trying to get out of the deadlock. If Libya is still a unified country, it is only because of the intervention of the foreign countries that helped the new government to face the contrasts between regions (Cyrenaica and Tripolitania were reunified in 1934 by Mussolini). In Egypt the political and institutional situation is unstable. After the 2011 revolution and the fall of Mubarak, Egypt was finally able to hold parliamentary elections but 2012 was marked by massive protests and riots against the government and President Morsi. In both cases, the coming months will tell us if we are approaching either stabilization or a new revolutionary/counter-revolutionary phase.

\section{I.3 MIDDLE EAST}

The group of countries which we usually refer to as the Middle East (Anglo-Saxon terminology) or Near East (French terminology) is the most heterogeneous in the Mediterranean area, not only from an economic point of view, but also from a political perspective.

In the space between the Dardanelles and Suez coexist two parliamentary republics (Israel and Turkey), a monarchy (Jordan), a dictatorship (Syria, officially an Islamic republic), a territory not yet internationally recognized as a state (Palestine) and a unique model of non-Western democracy (Lebanon).

According to the geopolitical perspective of the United States, this area corresponds to the western part of the Greater Middle East, the region of international security stretching from the eastern shores of the Mediterranean to Iran. ${ }^{1}$ It is perhaps the region in which geopolitical 
interests seem to be more closely linked to economic ones. It is one of the regions with the most impact on the perspectives of global foreign policy.

In Syria a new world war is in progress, involving on one side the Assad regime, which has been very slowly losing control, and on the other side various and separate oppositions, having as their unique common goal Assad's defeat. The USA and Europe oppose the Syrian regime but China and Russia have protected it during the UN Security Council. Whereas among the Mediterranean countries Turkey and Jordan are supporting the rebels, contributing to the isolation of Syria, on the other side Iran, its eastern neighbour, is one of the Assad regime's main partners.

A few kilometres southwards, the conflict between Israel and Palestine is far from being solved. After the Second World War the creation of two states in the territory of historic Palestine was proposed. Today, 65 years from the creation of the State of Israel, peace - which will have to go through the recognition of a Palestinian state - is still a chimera. Israel and Palestine do not seem to be able to communicate without the intervention of other counties or international organizations. Moreover, Palestinian people are divided geographically. The historic Palestine is divided into three areas, the largest of which is formed by the young and rampant State of Israel, bordered by two non-communicating territories, the Gaza Strip and the West Bank. Only one third of the Palestinian people live in these two areas. Despite the acquisition of 'non-member observer state' status at the UN, the definition of the Palestinian National Authority is shifty. The idea of 'two peoples, two States' remains a dream.

The future of the Middle East will depend on the evolution of the conflicts in Syria and Palestine, which inevitably involve the neighbouring countries. Among them, Turkey follows the Mediterranean vocation of 'bridge-state' between Asia, Europe and Africa. It is the most populous nation of the area, and it aims to play a leading role in the geopolitical chessboard of the Great Sea.

\section{I.4 SOUTHERN EUROPE}

From a political point of view Southern Europe and the Balkans are living in a period of deceptive calm ready to degenerate into instability if the economic troubles are not adequately faced.

It is not easy to give a unifying political outlook on the northern shore of the Mediterranean basin. The Italian peninsula always separated, not only geographically, West from East, Latin civilization from a conglomerate of young states in which Greek-Orthodox, Muslim and Christian populations were experiencing a difficult coexistence. 
Before becoming a sea, the Adriatic was for a long time a gulf, and before becoming a bridge, it was a trench dividing two ways of living, thinking and preaching. We are in the middle of a long path on which we have to understand where to go. The question is whether the Balkans are becoming a part of Europe or if a part of Europe is going to 'balkanize' itself.

Doubts are justified from the fact that the political process of European unification has begun to be questioned by public opinion in those countries (for example Italy) which were formerly the main promoters of the European Union and amongst its most enthusiastic supporters. The latest elections (in Italy and Greece) have also been seen as an opportunity for a kind of referendum for or against the European Union. A mutual distrust between the Northern and Southern European countries is currently developing. The stability of the Mediterranean northern shore's political panorama - Italy, Greece, Spain and Portugal - seems to be strictly connected to economic developments.

On the other hand, for the stability and the development of the process of European integration, the Balkans appear strategic on the perspective of a still distant but desirable Mediterranean integration. After Slovenia, Croatia will be the second of the six republics that were part of Yugoslavia to become a member of the EU (1 July 2013). The referendum of 2012 (67 per cent favourable) was significant because it demonstrated a desire to join the European Union, even if it was without any popular enthusiasm. The path to the European Union must necessarily first pass through the consolidation of recent national sovereignty. In Montenegro, for example, an official candidate for EU membership, the process of state building seems to be still in progress. Almost half of the citizens feel comfortable with the Serbian language rather than with the official Montenegrin one. At the basis of Balkan public life, with the constraints that arise in the political field, there is the question of the presence and coexistence of the majority and minorities, namely between different ethnicities, religions and cultures. The memory of the war is still too vivid. Macedonia, for example, acquired the status of official candidate for the European Union but is dealing with problems related to the presence of a large Albanian community. Three potential candidates for the European Union have similar problems to face: Albania, which is dealing with ethnic and religious conflicts; Serbia, which is dealing with the coexistence of Bosnian, Albanian and Kosovar minorities; and Bosnia-Herzegovina, where Croatian, Serbian and Muslim components are present. Kosovo, which has a large Serbian population in the north, declared itself independent in 2008, but is administrated by the $\mathrm{UN}$ and has still partial international recognition.

From a geopolitical point of view, the hegemonic influence of the 
United States, acquired on the northern part of the Western Basin since the Second World War and consolidated in the Balkans with the outbreak of the Yugoslav Wars in the 1990s, does not seem to be questioned.

Since the mid-twentieth century, Europe has chosen to build its union starting from economic cooperation. The ECSC (European Coal and Steel Community, 1952) and EEC (European Economic Community, 1957) were followed by the EU (European Union, its current name since 1993). The question is whether Europe has chosen the right track or whether the discouraging perspectives suggest the need for uniform policies as a preempting basis for the desired economic development.

\section{I.5 THE ECONOMIC PERSPECTIVE}

A book on the economic perspectives of the MENA countries at this very moment aims at highlighting those critical areas for the future development and growth of the area. The macroeconomic indicators are characterized by a great deal of uncertainty, and in particular GDP growth and unemployment, together with energy-related issues, represent the most relevant challenge in the medium term.

If we add that Gulf Cooperation Council countries (GCC) entered the scene as major players in the resetting of the political scenario of the Arab Spring countries, the uncertainty is even greater, as illustrated in the first chapter of this book. In particular, Valeria Talbot, in this political scenario assessment, describes the differentiated GCC countries' attitudes towards the events in Egypt, Tunisia and Libya.

Figure I.1 shows that the overall trend of per capita income in the MENA region has already recovered, after a slight contraction in 2009-10. The situation is very heterogeneous when considering the countries that are involved in the Arab Spring, though Libya, in particular, suffering a severe drop in 2011, immediately recovered in 2012. In general, however, the overall trend has recovered (see Figures I.1 and I.2).

The growth rate of the region remained very volatile after the drop experienced between 2007 and 2009, and it is expected to remain below long-term trends, as seen from Figures I.3 and I.4. ${ }^{2}$ This is mainly due to weak global demand, high food and fuel commodity prices and continued socio-political tensions and uncertainty.

Sluggish growth is not enough to stabilize the employment trend, with a population change that is expected to recover its long-term evolution (see Figure I.5).

Unemployment is thus increasing in many of the countries that experienced the Arab Spring (Figure I.6), with Egypt and Tunisia facing the most 


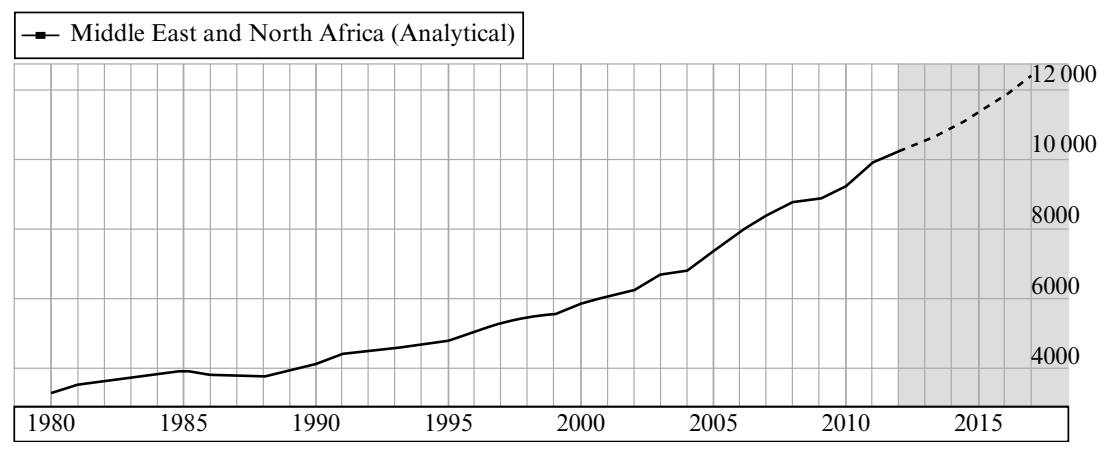

Note: GDP based on PPP per capita (current international dollars per capita).

Source: IMF World Economic Outlook, October 2012.

Figure I.1 Evolution of MENA region's GDP

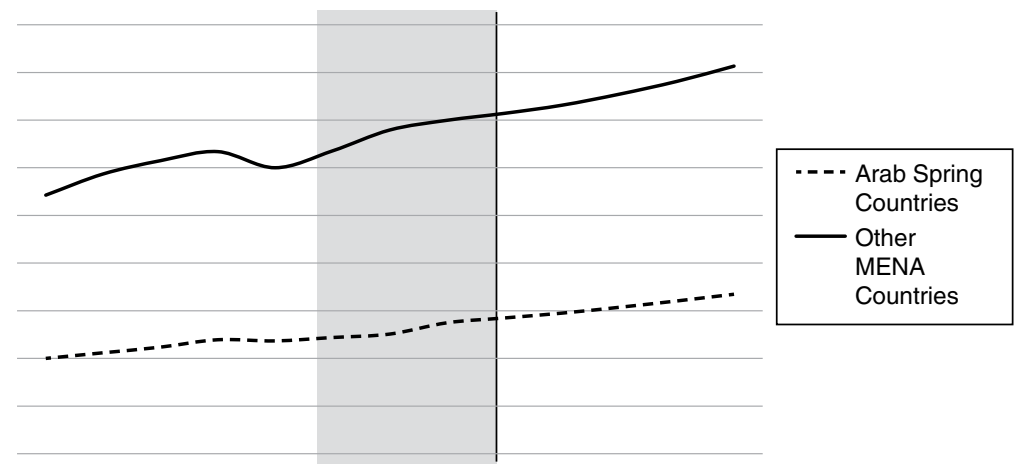

Note: a Arab Spring countries include Algeria, Egypt, Iraq, Jordan, Kuwait, Lebanon, Libya, Morocco, Oman, Syria, Tunisia and Yemen, where data are available, while other MENA countries include Bahrain, Djibouti, Iran, Israel, Malta, Qatar, Saudi Arabia and United Arab Emirates. The definition of MENA countries follows the World Bank: http:// web.worldbank.org/WBSITE/EXTERNAL/COUNTRIES/MENAEXT/0,menuPK:247619 pagePK:146748 piPK:146812 theSitePK:256299,00.html.

Source: IMF World Economic Outlook, October 2012.

Figure I.2 Recent evolution of GDP in MENA countries: Arab Spring countries $^{\mathrm{a}}$ vs. others 


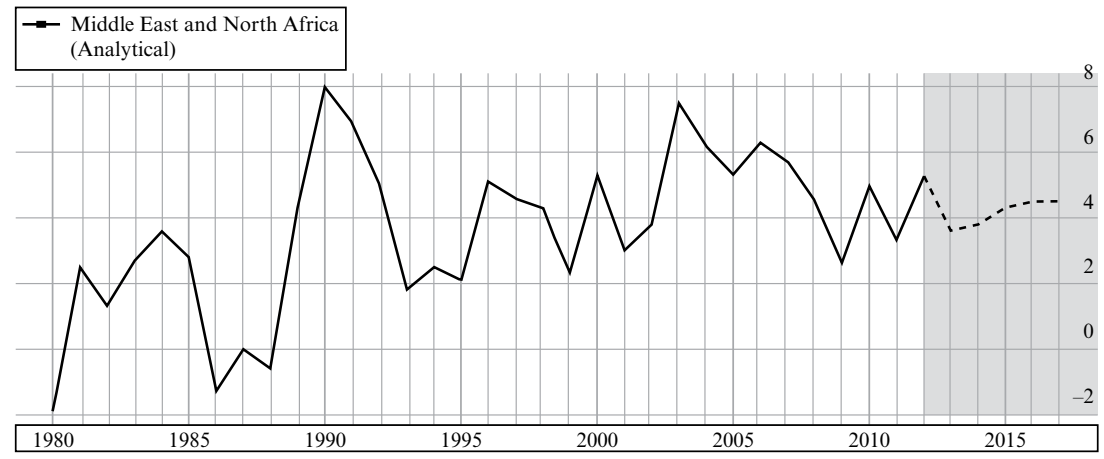

Note: Data represent GDP per capita in PPP.

Source: IMF World Economic Outlook, October 2012.

Figure I.3 Evolution of MENA region's real GDP growth (annual percentage change)

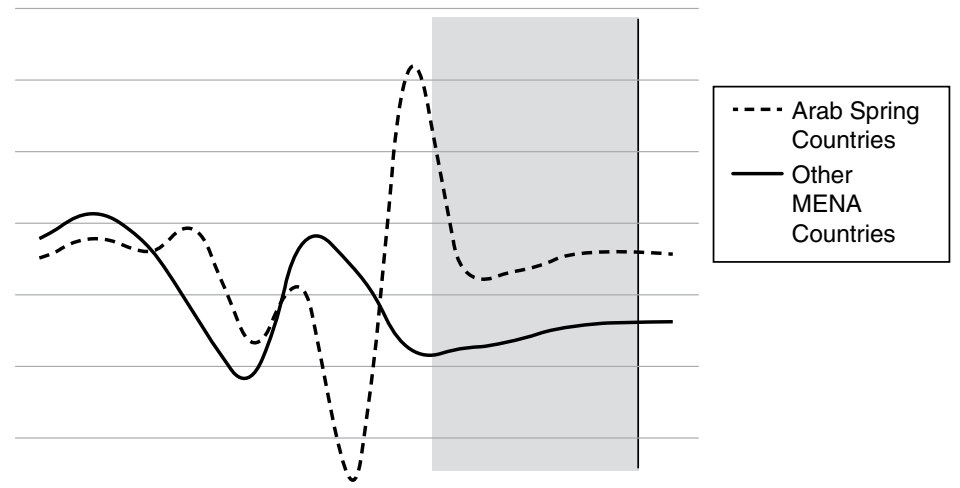

Note: Data represent real GDP growth, weighted average for each group of countries (weights based on GDP).

Source: IMF World Economic Outlook, October 2012.

Figure I.4 Recent evolution of GDP growth rate in MENA countries: Arab Spring countries vs. others

difficult situation in this regard, and it is expected to reach 2010 levels only in 2017.

Rising unemployment implies increasing deterioration of the business climate and job opportunities, as well as rising discrimination against 


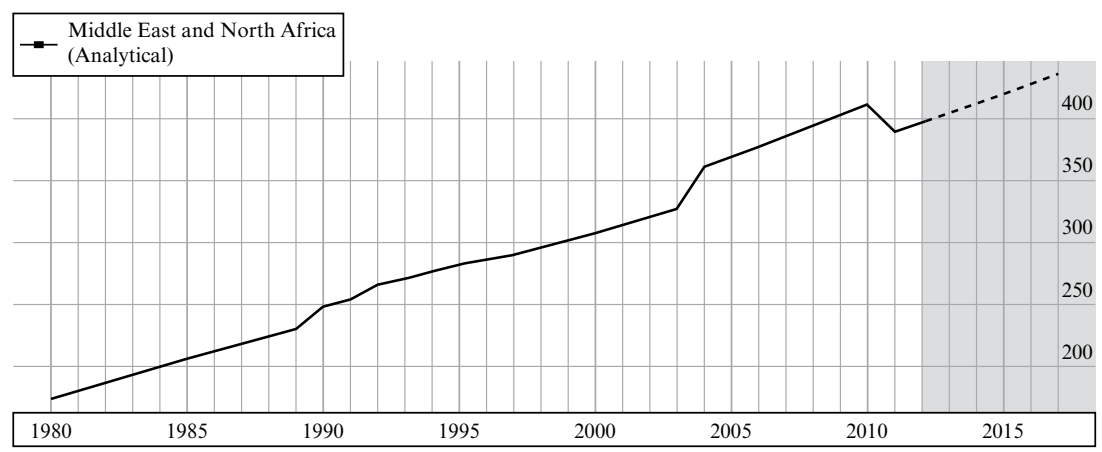

Source: IMF World Economic Outlook, October 2012.

Figure I.5 Evolution of MENA region's population (millions of people)

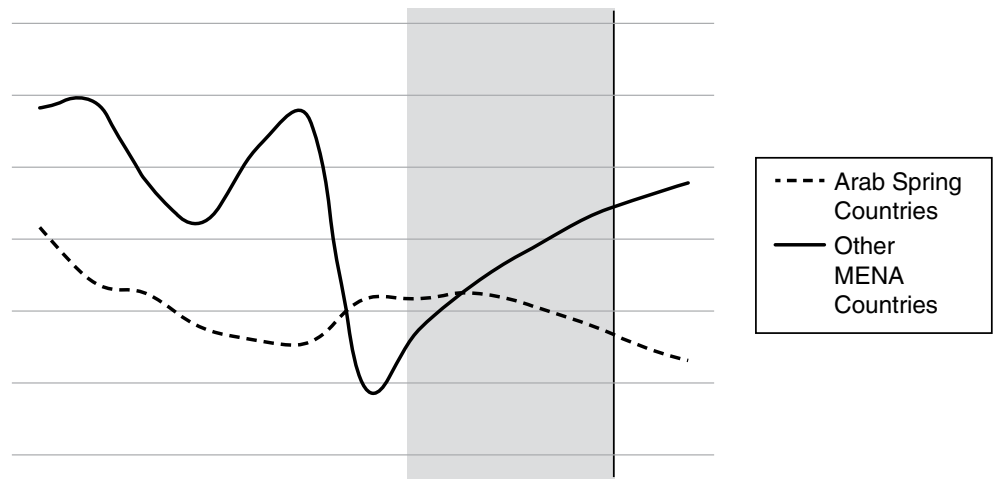

Note: Data represent unemployment rate, weighted average for each group of countries (weights based on GDP).

Source: IMF World Economic Outlook, October 2012.

Figure I.6 Recent evolution of unemployment rate in MENA countries: Arab Spring countries vs. others

women in the area. The specific relationship between trade, female labour and entrepreneurship is tackled in the empirical study by Contessi, de Nicola and Li (Chapter 4), who find that women are more likely to be business owners in female labour-abundant countries when they face fewer de jure constraints and operate in industries with a higher concentration of female workers.

Rising commodity prices and high unemployment are also driving an 


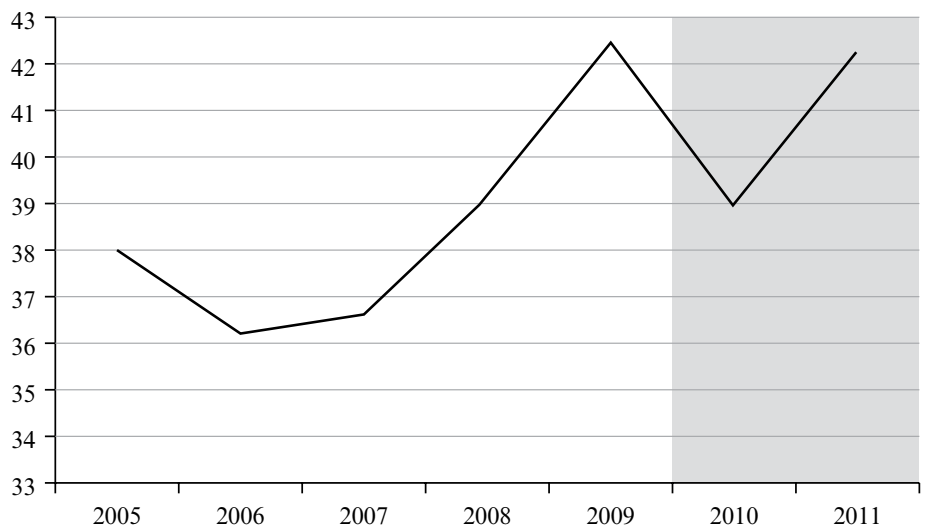

Note: Data represent government expenditure, as a percentage of GDP, average for the group of countries considered.

Source: IMF World Economic Outlook, October 2012.

Figure I.7 Recent evolution of government expenditure in Arab Spring countries

increase in government spending on wages and subsidies in the whole region (see Figure I.7), an instrument that can help in the short term, but that is not sustainable in the long term if a growth-lifting strategy is not employed.

Inflation has increased sharply since 2010, but it is expected to slow down in the near future (see Figure I.8) and stabilize in the majority of countries (see Figure I.9).

The current account balance is also expected to deteriorate, as depicted in Figure I.10. The MENA countries have been traditionally seen to be under-trading with each other, with the typical pattern of trade becoming much more like a hub and spoke structure with Europe in the middle. But in the recent past, as Asian economies became dominant in the international scenario, things have been changing slightly; the decline in the over-trading of MENA countries with the EU and the US has been accompanied by the decline in under-trading among MENA countries themselves and also with Asian countries, as illustrated in the trade discussion of Arian Farshbaf and Jeffrey Nugent (Chapter 2).

Moreover, the deterioration of external competitiveness of the region is also confirmed by the deterioration of Foreign Direct Investment (FDI) attractiveness since the beginning of the Arab Spring for the whole MENA region, a negative trend that inverted the positive, although volatile, trend 


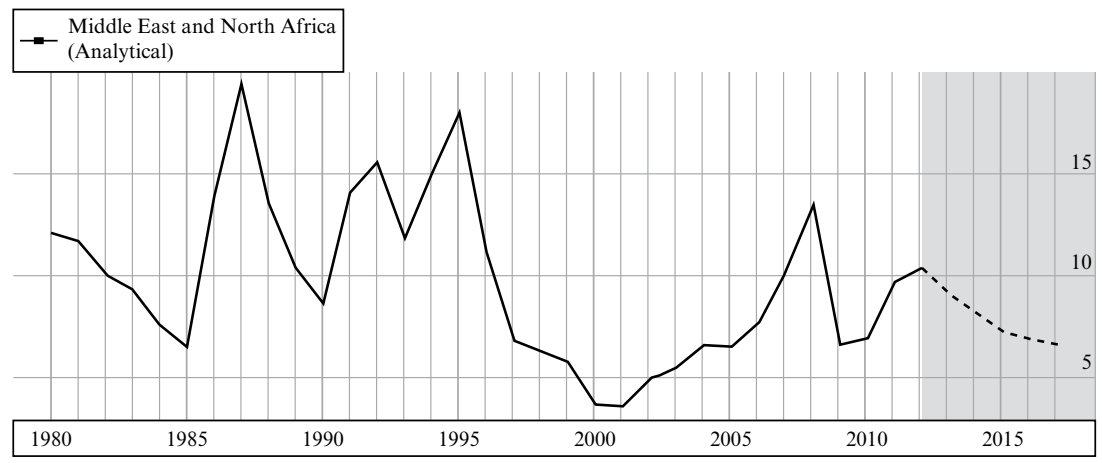

Source: IMF World Economic Outlook, October 2012.

Figure I.8 Evolution of MENA region's inflation rate (average consumer prices; annual percentage change)

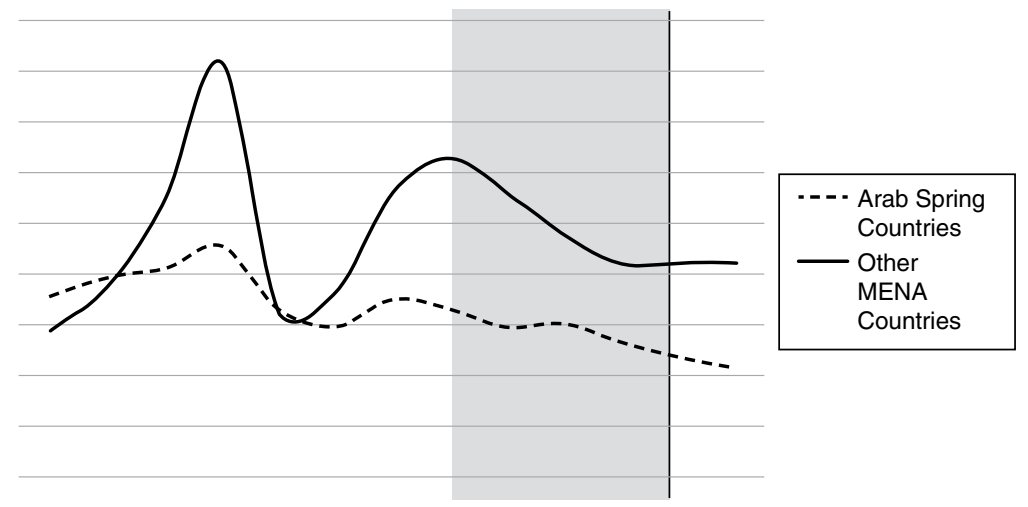

Note: Data represent inflation rate (annual \% change CPI), weighted average for each group of countries (weights based on GDP).

Source: IMF World Economic Outlook, October 2012.

Figure I.9 Recent evolution of inflation in selected Arab countries

of previous years (see Figure I.11) and worsened the impact of the global economic crisis (see Figure I.12).

FDI plays a role in providing fresh capital, external financing possibilities, know-how and technologies to the host countries; these benefits potentially lead to spillovers of various kinds, but they also contribute to labour creation, therefore the linkage with employment-related issues is 


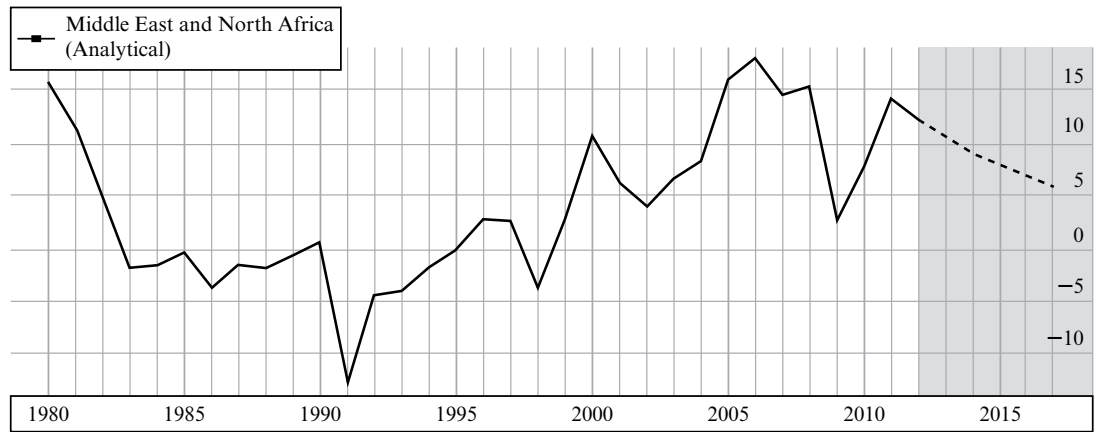

Source: IMF World Economic Outlook, October 2012.

Figure I.10 Evolution of MENA region's current account balance (percentage of GDP)

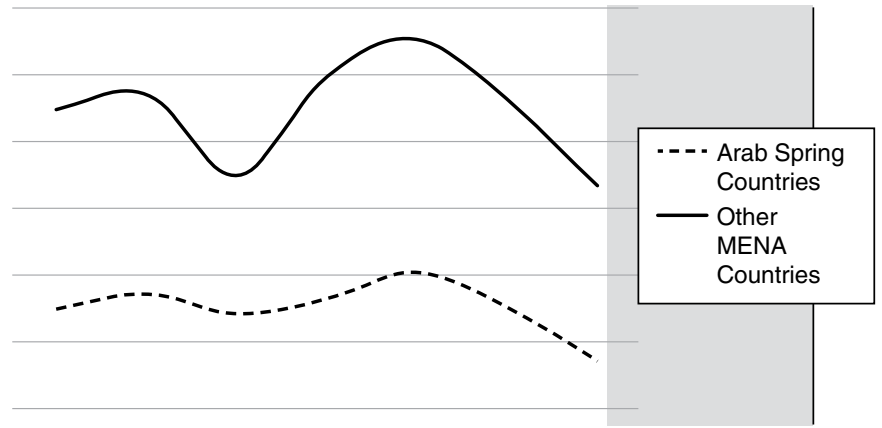

Note: Average performance of the countries belonging to each group.

Source: UNCTAD Database, UNCTADStat.

Figure I.11 Evolution of FDI inflows, as percentage of world's total in MENA countries

self-evident, and is discussed in the chapter on productivity, labour and FDI by Sergio Alessandrini (Chapter 3).

The financial scenario was heavily affected by the political turmoil in the area, with investors acting cautiously as long as the scenario was unstable. However, the increase in the consolidated $\mathrm{CDS}^{3}$ for the Middle East region has slowed down in the last year, signalling a positive consideration of financial markets of the first signs of restored political stability in many MENA countries (see Figures I.13 and I.14). 


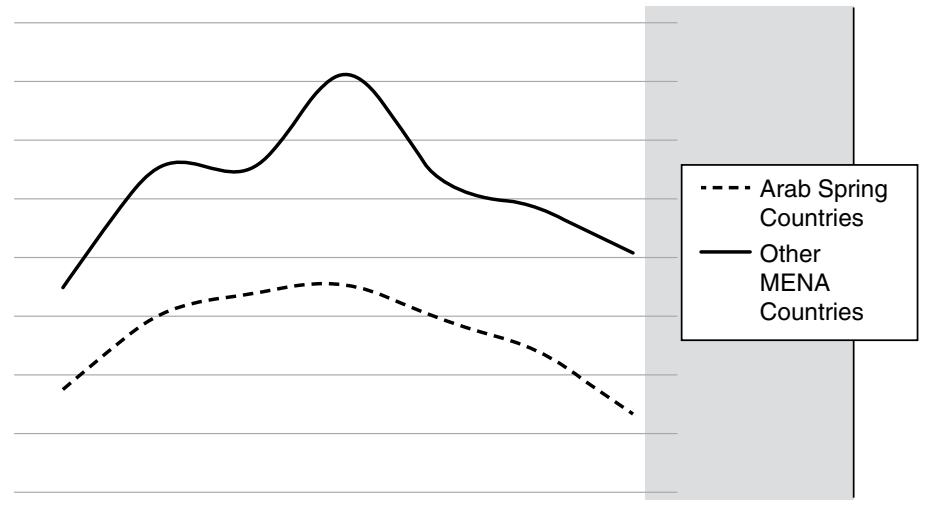

Note: Data are expressed at current prices and current exchange rates, total inflows in each region.

Source: UNCTAD Database, UNCTADStat.

Figure I.12 Evolution of FDI inflows, in millions of US dollars

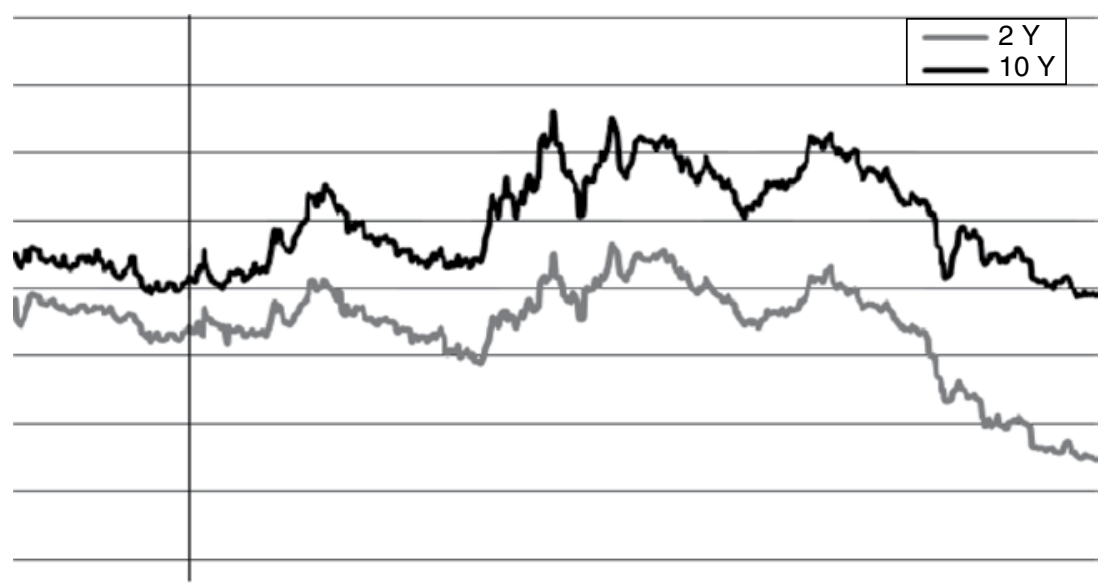

Source: Bloomberg.

Figure I.13 Evolution of Middle East 2 years and 10 years CDS 


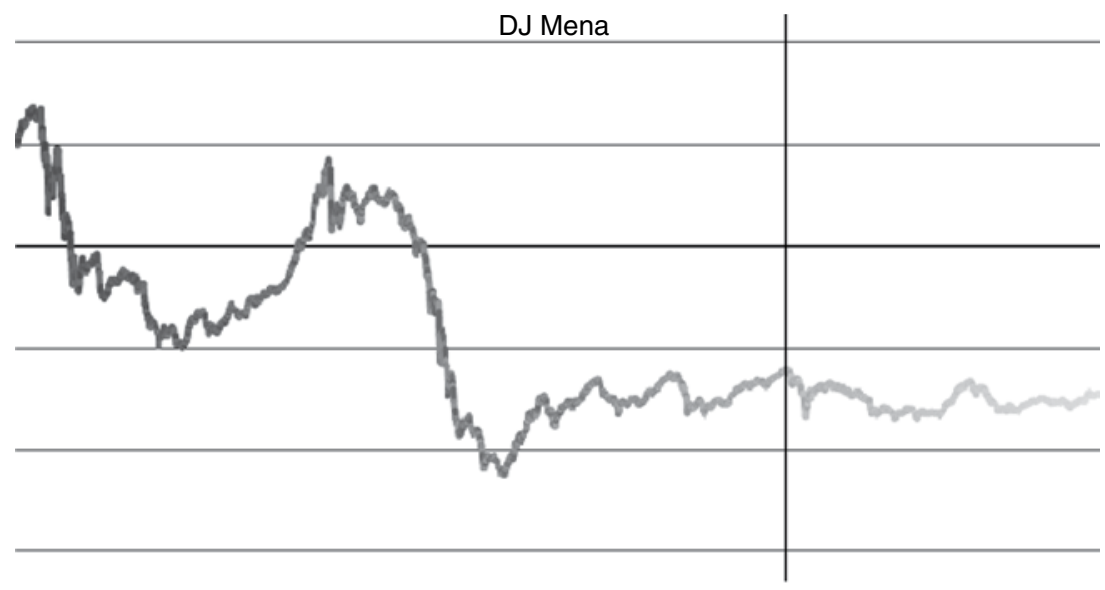

Source: Bloomberg.

Figure I.14 Evolution of Dow Jones Index for the MENA region

The macroeconomic outlook just depicted thus highlights that recovery still appears quite slow and fragile in the region, and the full rehabilitation of MENA economies depends largely on the path of socio-economic reforms that will be undertaken in the near future.

Some positive signals in this perspective came from the recent economic summit that took place in Riyadh in January 2013 and represented the first economic summit of Arab leaders since the Arab Spring started. During the 3rd Arab Economic Summit, indeed, traditional issues such as the pan-Arab free trade area and support for SMEs in the area were coupled with completely new topics inspired by the Arab Spring. These include the urge to tackle unemployment or the problem of 'non-existent' job opportunities for a young, highly educated new generation or the importance of the untapped potential of Arab women who are increasingly educated and eager to make their contribution to the economic success of the region. Other crucial topics for the development of the region were redefined and substantiated, such as environmentally sustainable development.

These new themes and important priorities for the future of the MENA regions' countries are the focus of this book. Considering the problem of youth unemployment, Farshbaf and Nugent find that the young workforce who have very few prospects in their home countries could prove crucial in improving the classical problem of under-trading of the region. Focusing on the untapped potential of Arab women, Contessi, de Nicola and Li 
propose a gender study in the realm of international trade. Since MENA countries stand out in international comparisons for de jure obstacles to female employment and entrepreneurship, they analyse female labour participation and find that women are more likely to be business owners in female labour-abundant countries when they face fewer de jure constraints and operate in industries with a higher concentration of female workers. The problem of high unemployment in the region in general is also addressed by Alessandrini (Chapter 3), who discusses the contribution of foreign capital inflows to domestic employment and labour productivity. Using the input-output matrix, the author finds strong and significant positive effects from the backward spillovers of FDI on productivity and employment.

As far as environmental issues of sustainable development are concerned, Nicolini and Porcheri (Chapter 6) describe the actual energy scenario and stress the importance of the Arab Spring in deterring and postponing large investments in the area. Bayar and Youssef (Chapter 5) go further by considering the way in which energy is produced, distributed and used and the way it affects the social, economic and environmental dimensions of any development efforts. Since climate also depends on energy production, $\mathrm{CO}_{2}$ emissions and the use of alternative energies are also investigated.

Finally, in the last chapter of this book, Bosco and Mavilia discuss long-term growth and innovation, drawing attention to the fragility of any growth policy that focuses only on trade integration, but is based on risible figures for R\&D expenditure and human capital formation.

\section{NOTES}

1. G8 definition. A wider definition includes the countries from the Atlantic shore of the Maghreb to Central Asia.

2. Note that the negative peak of 2011 and the positive peak of 2012 for Arab Spring countries in Figure I.4 is mainly driven by the performance of Syria.

3. A CDS is a swap designed to transfer the credit exposure of fixed-income products between parties. The buyer of a credit default swap receives credit protection, whereas the seller of the swap guarantees the creditworthiness of the debt security. In doing so, the risk of default is transferred from the holder of the fixed-income security to the seller of the swap. For example, the buyer of a credit default swap will be entitled to the par value of the contract by the seller of the swap, should the third party default on payments. By purchasing a swap, the buyer is transferring the risk that a debt security will default. 


\section{REFERENCES}

Braudel, F. (1949), La Méditerranée et le Monde Méditerranéen à l'Epoque de Philippe II, Paris: Librairie Armand Colin.

Huntington, S. (1991), The Third Wave: Democratization in the Late Twentieth Century, Norman, OK: University of Oklahoma Press.

Huntington, S. (1996), The Clash of Civilizations: Remaking of World Order, New York: Simon \& Schuster. 